\title{
A brief molecular insight of COVID-19: epidemiology, clinical manifestation, molecular mechanism, cellular tropism and immuno-pathogenesis
}

\author{
Sweta Singh ${ }^{1} \cdot$ Rakesh Pandey $^{1} \cdot$ Sarika Tomar $^{1} \cdot$ Raunak Varshney $^{2} \cdot$ Darshika Sharma $^{1,3}$. \\ Gurudutta Gangenahalli ${ }^{1}$ (i)
}

Received: 3 November 2020 / Accepted: 23 June 2021 / Published online: 30 June 2021

(c) The Author(s), under exclusive licence to Springer Science+Business Media, LLC, part of Springer Nature 2021

\begin{abstract}
In December 2019, the emergence and expansion of novel and infectious respiratory virus SARS-CoV-2 originated from Wuhan, China caused an unprecedented threat to the public health and became a global pandemic. SARS-CoV-2 is an enveloped, positive sense and single stranded RNA virus belonging to genera betacoronavirus, of Coronaviridae family. The viral genome sequencing studies revealed $75-80 \%$ similarity with SARS-CoV. SARS-CoV-2 mainly affects the lower respiratory system and may progress to pneumonia and Acute Respiratory Distress Syndrome (ARDS). Apart from lifethreatening situations and burden on the global healthcare system, the COVID-19 pandemic has imposed several challenges on the worldwide economics and livelihood. The novel pathogen is highly virulent, rapidly mutating and has a tendency to cross the species boundaries such as from bats to humans through the evolution and natural selection from intermediate host. In this review we tried to summarize the overall picture of SARS-CoV-2 including origin/ emergence, epidemiology, pathogenesis, genome organization, comparative analysis with other $\mathrm{CoVs}$, infection and replication mechanism along with cellular tropism and immunopathogenesis which will provide a brief panoramic view about the virus and disease.
\end{abstract}

Keywords SARS-CoV-2 $\cdot$ COVID-19 $\cdot$ Pandemic $\cdot$ Infection $\cdot$ Pathogenesis

\section{Introduction}

Recent mysterious pneumonia that spread worldwide and known to have an origin at the seafood and animal market, in Wuhan, China has become global pandemic and given the name "2019-nCoV" by World Health Organization (WHO). Further, the International Committee of Virus Taxonomy

Rakesh Pandey and Sarika Tomar have contributed equally to the work.

Gurudutta Gangenahalli gurudutta.inmas@gmail.com

1 Division of Stem Cell and Gene Therapy, Institute of Nuclear Medicine and Allied Sciences, Brig. S. K. Mazumdar Road, Delhi 110054, India

2 Division of Cyclotron and Radiopharmaceutical Sciences, Institute of Nuclear Medicine and Allied Sciences, Brig. S. K. Mazumdar Road, Delhi 110054, India

3 Meerut Institute of Engineering and Technology, Meerut, India classified this new virus as SARS-CoV-2 (Severe Acute Respiratory Syndrome coronavirus) based on standard practice, pathology, phylogeny and taxonomy [1]. SARS-CoV-2 known to be originated from bat coronavirus and transmitted to humans due to its ability to cross species barrier from bats to humans [2]. In the past two decades, coronaviruses are responsible for the three epidemics namely COVID-19, SARS and MERS. This novel SARS-CoV-2 is a zoonotic virus, belong to Coronaviridae family of Nidovirales order [3]. This family got its name "coronavirus" because of the crown-like appearance of its spike protein. The Coronavirus family is composed of four subgroups i.e. alpha $(\alpha)$, beta $(\beta)$, gamma $(\gamma)$ and delta $(\delta)$. Two subgroups the alpha $(\alpha)$, beta $(\beta)$, mainly affect mammalians, whereas the other two subgroups, gamma $(\gamma)$ and delta $(\delta)$ primarily affect birds [4]. Till date, seven kinds of human coronavirus have been identified out of which two belongs to alpha $(\alpha)$, HCoVNL63 and HCoV-229E and five belongs to beta ( $\beta$ ) HCoVOC43, HCoV-HKU1, SARS-CoV (severe acute respiratory syndrome corona virus), MERS-CoV (Middle East respiratory syndrome coronavirus) and SARS-CoV2. The size of 
corona viruses range from 65 to $125 \mathrm{~nm}$ in diameter with a crown-like feature on the exterior surface. Genetically, Coronavirus is single-stranded positive-sense RNA with a relatively larger genome composition of 26 to $32 \mathrm{kbs}$. Its genome composed of 6-10 open reading frames (ORFs), in which first ORF constitutes largest part of genome and other ORFs encode accessory and structural proteins. SARS-CoV-2 is different from SARS-CoV as seen in phylogenetic report and genomic sequencing. During last one year, it has become more virulent by undergoing frequent mutation thereby making it difficult to associate a particular strain with the severity of the disease. The binding of virus to host cell is the main determinant for the viral pathogenesis and designing of any antiviral therapy. Angiotensin-converting enzyme (ACE2) a Type 1 membrane glycoprotein which is highly up-regulated in the lungs and endothelial cells acts as a primary receptor for the viral entry and physiologically important in the progression of COVID-19 disease and illness [5]. This virus mainly affects the lower respiratory system and causes pneumonia similar to other beta coronaviruses SARS-CoV and MERS-CoV. Apart from the lower respiratory system it is also affecting gastrointestinal system, liver, heart, and kidney and leading to multiple organ failure [6, 7]. The extra pulmonary manifestations such as diarrhoea, impaired liver function, chronic renal disease etc. suggests viral tropism/ affinity for the non-pulmonary tissues [5].

\section{Epidemiology}

The novel coronavirus, SARS-CoV-2 outbreak that started from Wuhan, China in December has been globally spread and imposed a severe threat to the people's health. China, the epicenter of the COVID-19 pandemic reported 4653 deaths and 89,000 confirmed cases. As per WHO latest report, more than 200 countries are threatened with more than 146 Million confirmed cases and over 3.1 Million deaths globally (Fig. 1) while more than one billion patients have given vaccine doses (232 Million fully vaccinated). Apart from life-threatening situations and huge burden on the global healthcare system, the COVID-19 pandemic has imposed several other challenges on economy, livelihood, individual freedom and social life. Besides confirmed cases; millions people were in quarantine/isolation for several months. To combat the pandemic, several countries have posed nationwide/statewide lockdown. Still several countries and states are in lockdown or under some sort of curb/curfew as world is witnessing second/third wave. Worldwide lockdown has

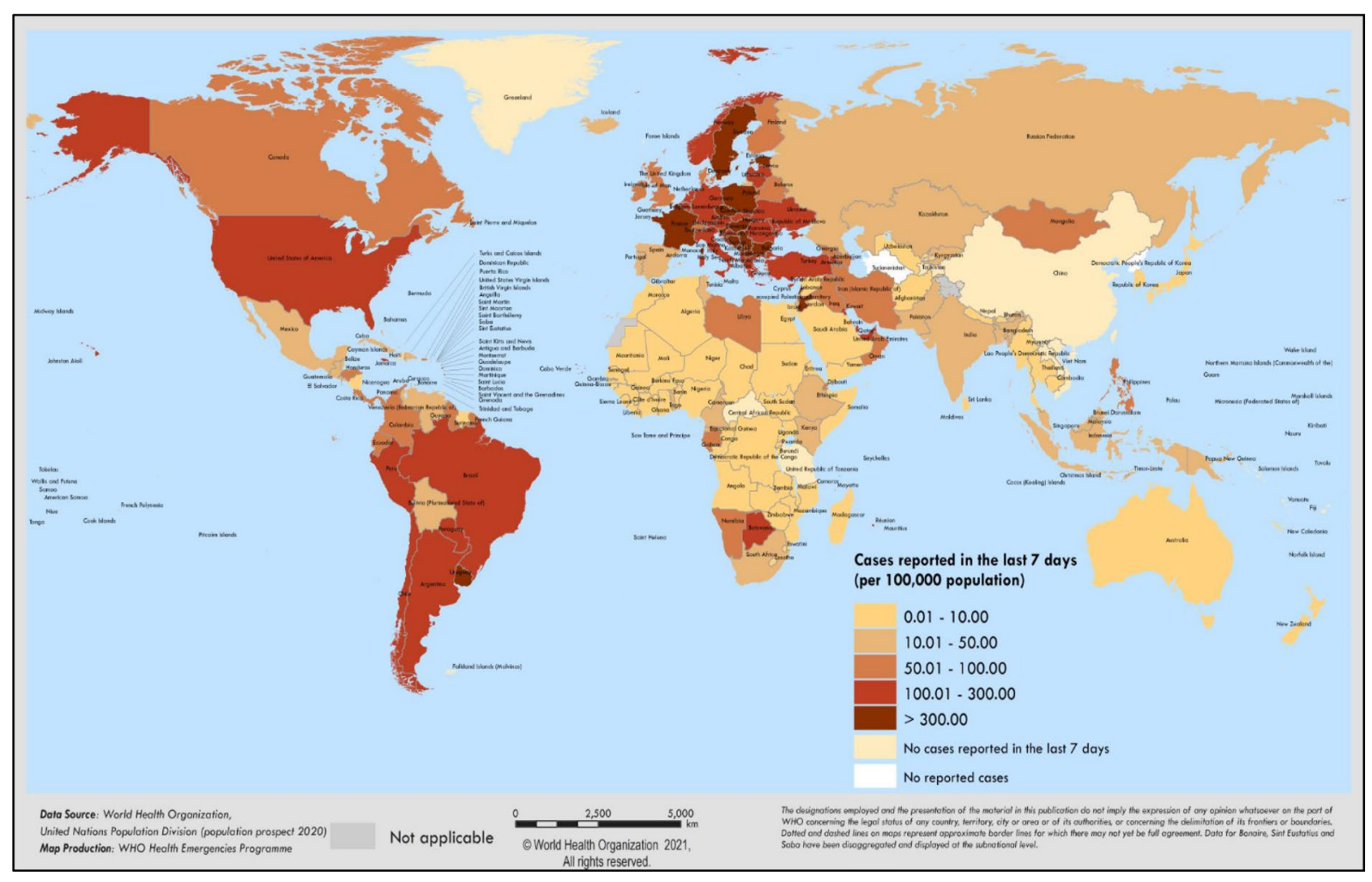

Fig. 1 Countries, territories or areas with reported confirmed cases of COVID-19, 30 March 2021 ( Source: www.who.int/emergencies/diseases/ novel-coronavirus-2019/situation-reports) 
imposed different kinds of psychological challenges among people and also affected the livelihood of millions.

\section{Symptoms, age, sex and CFR}

The recent outbreak of pandemic COVID-19 is known as a respiratory disease caused by SARS-CoV-2 (https://www. who.int/westernpacific/emergencies/COVID-19). Chinese Centre for Disease Control and Prevention (China CDC) published a detailed analysis of 44,672 confirmed cases on February 14th. The clinical manifestations of COVID19 could be both asymptomatic and symptomatic that include fever, sore throat, dry cough, tiredness, shortness of breath, ARDS (Acute respiratory distress syndrome), and pneumonia with varying degrees of severity. Complaints of gastrointestinal symptoms such as diarrhoea, nausea and vomiting, and myalgia or fatigue are also seen during illness [8-14]. The estimated CFR (case fatality rate) for COVID-19 is 3.4\% up to March which is much higher than the flu (Fig. 2). As per the China CDC, 14\% of patients were severe while $81 \%$ of patients showed only mild symptoms i.e. non-pneumonia and mild pneumonia, and no death was reported in this case [15]. 49.0\% CFR was reported in 5\% critically ill with respiratory failure, septic shock, and multiple organ failure. Total CFR was $2.3 \%$ while out of total fatality only $2.2 \%$ of patients were below 20 years. As per various reports children appeared to be at lower risk. CFR in the age group 70-79 was $8 \%$ while it was $14 \%$ in the age group 80 and above. Higher CFR was reported among the patient with pre-existing chronic ailments such as cardiovascular disease (10.5\%), diabetes $(7.3 \%)$, chronic respiratory disease $(6.3 \%)$ and hypertension (6\%). Variable CFR has been seen based of region/country. Variable CFR has been seen based of region/country. Variability in CFR would be very common as its depends on many factors such as socioeconomic condition, healthcare infrastructure, level of preparedness, population, co morbidity in population, testing capacity per million etc. in the particular country.

Till the date, no sex-disaggregated data on SARSCoV-2 susceptibility towards infection and both males and females are equally infected with COVID-19. However, there is few reports on sex disaggregated data on mortality and vulnerability towards the disease that suggest that male mortality is higher than female. As per one report published in Lancet, male to female ratio was found to be $80 \%$ to $20 \%$ (median age of 79.9 years for men and women for 83.4 years for women) [16]. Another report stated that male patient were more severely affected than female $(P=0.035)$ and mortality of male were 2.4 times higher than female (70.3 vs. $29.7 \%, P=0.016$ ) [17].

Low rate mortality in women could be due to sex-based immunity, low smoking, and drinking as compared to men. However, there is no conclusive understanding yet as sexdisaggregated data are insufficient and it would be too early to conclude anything at this stage.

\begin{tabular}{|c|c|c|c|c|}
\hline Disease & Flu & COVID-19 & SARS & MERS \\
\hline $\begin{array}{r}\text { Disease Causing } \\
\text { Pathogen }\end{array}$ & Influenza virus & SARS-CoV-2 & SARS-CoV & MERS-CoV \\
\hline $\begin{array}{r}\mathrm{R}_{0} \\
\text { Basic Reproductive Number }\end{array}$ & 1.3 & $2.0-2.5^{*}$ & 3 & $0.3-0.8$ \\
\hline $\begin{array}{r}\text { CFR } \\
\text { Case Fatality Rate }\end{array}$ & $0.05-0.1 \%$ & $\sim 3.4 \% *$ & $9.6-11 \%$ & $34.4 \%$ \\
\hline Incubation Time & 1 - 4 days & $4-14$ days * & $2-7$ days & 6 days \\
\hline Hospitalization Rate & $2 \%$ & $\sim 19 \% *$ & Most cases & Most cases \\
\hline Community Attack Rate & $10-20 \%$ & $30-40 \% *$ & $10-60 \%$ & $4-13 \%$ \\
\hline Annual Infected (global) & $\sim 1$ billion & N/A (ongoing) & 8098 (in 2003) & 420 \\
\hline
\end{tabular}

Fig. 2 Epidemiological comparison of respiratory viral infections 


\section{Incubation period}

The incubation period is crucial information for active healthcare monitoring and taking proactive measures to stop the spreading. One of the very first reports estimated a mean incubation period of 5.2 days based on ten confirmed cases [18]. Another report claimed the median incubation period of 4.75 (interquartile range: 3-7.2) days based on the study of 125 patients with confirm exposure [19]. A study based on 158 confirmed cases reported a median incubation period of 5.0 days (CI, 4.4 to 5.6 days) [20]. However, estimation on incubation period based large sample size suggested only 3.0 days median incubation period and could be as long as 24 days [21]. There is strong possibility that this RNA virus invades the host innate immune system, a first-line host defence, to evade immune detection. Also, genetic variation plays an important role in the variable host immune response. These may be the reasons behind the long and variable incubation period. There is a possibility that a high incubation period plays a role in the degree of pathogenicity.

A study performed on 1099 patients to determine the viral load and transmission potential during the incubation period in both symptomatic and asymptomatic patients found to be higher soon after the onset of symptoms similar to influenza [22]. Viral load in both symptomatic and asymptomatic patients was quite similar indicating the transmission potential of both asymptomatic patients as well as symptomatic patients $2-3$ days prior to the onset of symptoms. The role of asymptomatic patients in the transmission of infection is yet to be defined. Larger cohorts data will be needed to understand the disease and transmission dynamics. However, primary reports/studies led countries to strategies different measures such as quarantine, isolation and tracing/testing to minimize the transmission.

\section{Origin and reservoir}

Recent genomic data indicate that the most closely related virus to SARS-CoV-2 originated from bats [23-25]. Genomic sequence of sampled virus from bat from Yunnan province approximately $1500 \mathrm{~km}$ away from epicentre Wuhan showed 96\%-97\% similarity with SARS-CoV-2. Practically these viruses will take almost 15-20 year to evolve to SARS-CoV-2 which suggests the possibility of multiple intermediate hosts. Current findings suggest that bats are most anticipated reservoir hosts for SARSCoV-2, but there is a strong possibility of 'intermediate' host that augmented SARS-CoV-2 to acquire some desired mutations to become virulent to human transmission as it happened in case of MERS and SARS where camels and civets were intermediate hosts, respectively. MERS$\mathrm{CoV}$ was supposed to be present in camels for almost a decade and through multiple cross-species transmission, it appeared in humans. A strong possibility is that these animals could be true reservoir hosts of SARS-CoV-2 [26].

Another intriguing finding is that none of bat corona virus sequenced from Hubei province was found close to SARSCoV-2 in phylogenetic trees. [27] One interesting report revealed that the virus found in Malayan pangolins (Manis javanica) is closely related to SARS-CoV-2 and showed strong similarity to the RBD sequence of SARS-CoV-2 along with six key residues important for ACE2 receptor binding. However, the rest of the genome of SARS-CoV-2 was distant from this pangolin-associated coronavirus. This study suggests that pangolins could be another possible intermediate host in the rise of novel SARS-CoV-2 outbreak. Closest bat CoV RaTG13 virus genomic sequence showed 96-97\% similarity with SARS-CoV-2 though spike protein diverges in bat virus. Natural selection is currently the most probable answer for the origin of SARS-CoV-2 infecting a primary and intermediate hosts and finally reaching to humans. However, current findings and research are not sufficient to provide complete information on natural host or intermediate host of SARS-CoV-2.

\section{Peculiar features, mutation and insertion in SARS-COV-2 genome}

\section{Genome Organization and predisposition}

SARS CoV-2 as other corona viruses belong to the order Nidovirales and family Coronaviridae of the betacoronavirus genera [28]. SARS-CoV-2 is a single stranded positive sense virus having 29,891 nucleotides $(\mathrm{G}+\mathrm{C}=38 \%)$ encoding 9860 amino acids. Its genome contains two untranslated region (UTR) and one long open reading frame (ORF) that codes for the polyprotein. S protein of SARS-CoV-2 is also distinct from other coronavirus in the subgenus Sarbeco virus [29]. S protein of SARS-CoV-2 possess a size of 1273 amino acids while it is 1255 amino acids and 1245-1269 amino acids in case of SARS-CoV and bat SARS-CoV. In term of sequence similarity, SARS-CoV-2 $\mathrm{S}$ protein has 76-77\% similarity from civet and human but surprisingly higher similarity $90.7-92.6 \%$ with pangolin coronavirus [30].

The sequential arrangement of genes from $5^{\prime}-3^{\prime}$ is ORF1a, ORF1b, S, ORF3, E, M, and N in SARS-CoV-2 which is distinct in its genera [31] (Fig. 3). Also, SARS$\mathrm{COV}-2$ lacks the hemagglutinin esterase gene which is present as a component of the structural gene in SARS-CoV 


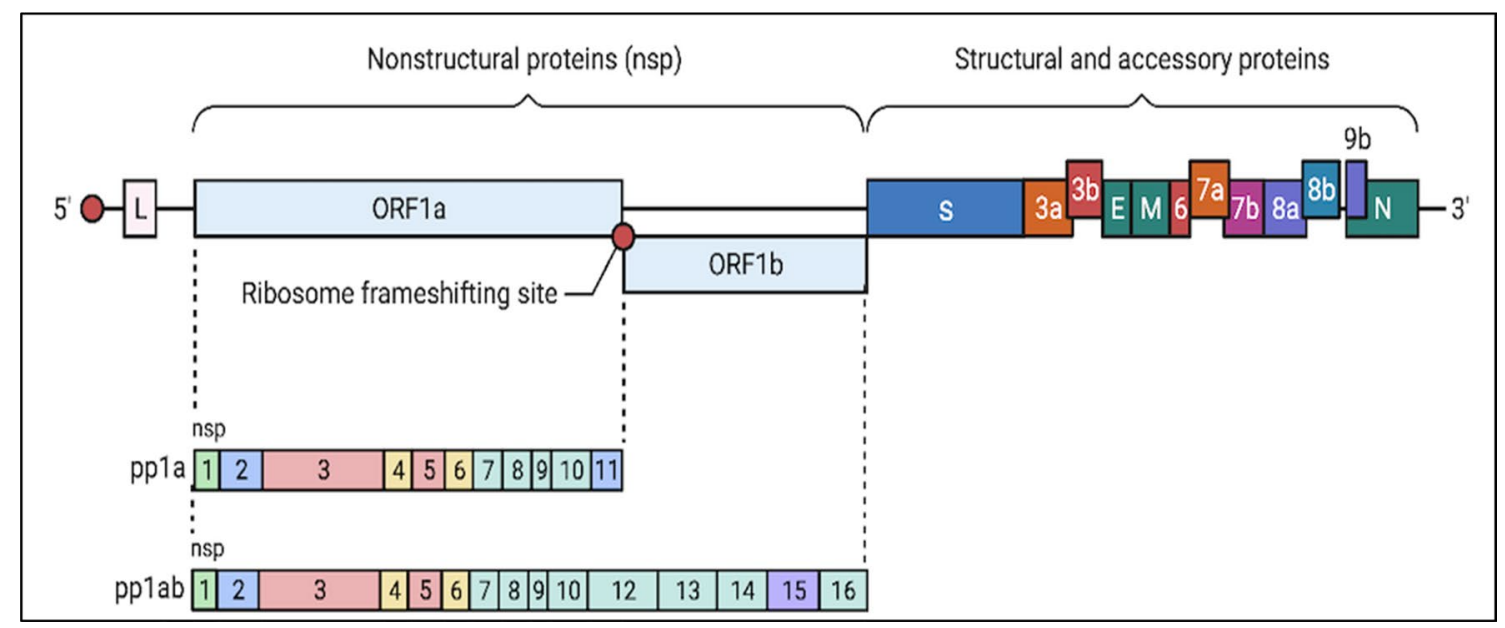

Fig. 3 Genome organization of SARS-CoV-2

Table 1 Comparison of proteins of SARS-CoV and SARS-CoV-2

\begin{tabular}{lll}
\hline Proteins & SARS-CoV & SARS-CoV-2 \\
\hline $8 \mathrm{a}$ & Present & Absent \\
$8 \mathrm{~b}$ & Shorter, 84aa & Longer, 121aa \\
$3 \mathrm{~b}$ & Longer, 154aa & Shorter, 22aa \\
\hline
\end{tabular}

and MERS-CoV [29]. There are no major differences in the nsps and ORFs of SARS-CoV-2 and SARS-CoV except at some particular proteins [32]. Recent works reported 116 mutations along with three common mutations in the ORF1ab gene at C8782T, in the ORF8 gene at T28144 C and in the $\mathrm{N}$ gene at $\mathrm{C} 29095 \mathrm{~T}$ based on bioinformatics analysis of 95 complete genomic sequence of SAR-CoV-2 available till 05 April 2020 [33]. Pb1ab is the first ORF starting from $5^{\prime}$ end which encodes a nonstructural protein of size 29844 bp, 29751 bp, and 30119 bp in SARSCoV-2, SARS-CoV and MERS-CoV respectively. The length of spike protein is significantly different in CoVs. The length of spike protein at the $3^{\prime}$ in SARS-CoV-2 is 1273aa while 21493aa and 1270aa in SARS-CoV and MERS-CoV respectively [31].

A comparative analytical study of the transmembrane region of SARS-CoV-2 nsp2 and nsp3 with SARS-CoV revealed that mutation occurs at 723aa (glycine to serine) and 1010aa (isoleucine to proline) positions [34]. The functional significance of these changes is still unknown but these are mostly related to the virulence of the virus.

Nsp7, nsp13, E protein, and accessory proteins $\mathrm{p} 6,8 \mathrm{~b}$ do not show any mutation. As evident by the genomic similarity of SARS-CoV-2 with SARS-CoV, the amino acid organization is also quite similar except some notable differences in the accessory proteins present at the 3 'end [35] (Table 1).

\section{High affinity to angiotensin converting enzyme 2 (ACE-2)}

The crystal structure revealed that SARS-CoV RBD is composed of two major structures: a core structure and a receptor-binding motif (RBM) that binds to the outer surface of the ACE2 receptor [36]. Further, another study demonstrated that SARS-COV-2 bound strongly to human and bat ACE-2 and even inhibited the binding of SARS-COV to ACE2. [37]. Sequence alignment studies of the amino acid (aa) of SARS-CoV-2 S protein with SARS-CoV S protein revealed $[38,39]$ the complete structural and functional domain in SARS-CoV-2 S protein. S1 segment (aa14-685) consists of N-terminal domain (aa14-305), RBD (aa319-541) along with RBM (aa437-508)) and S2 segment (aa686-1273) consists of fusion domain (aa788-806), HR1 (aa912-984), HR2 (aa1163-1213), TM domain (aa1214-1237) and cytoplasmic domain (aa1238-1273) [40]. Residues from 318 to 510 in the S1 region are enough for high-affinity binding to the peptidase domain of ACE2 [41]. Sequence alignment study between SARS-CoV-2 and SARS-CoV spike has revealed that they share $76 \%$ to $78 \%$ identity in the whole spike protein and approximately $73 \%$ to $76 \%$ identity in the receptor binding domain and around 50\% to 53\% similarity in RBM. [36].

A total of 27 amino acid substitutions have been discovered in spike protein which comprises of 1273 amino acids. Six amino acid residues L455, F486, Q493, S494, N501 and Y505 in SARS-CoV-2 which corresponds to Y442, L472, N479, D480, T487 and Y491 in SARS-CoV RBD, are crucial for ACE2 receptor binding. Out of six crucial amino acid residues five are substituted in SARS-CoV-2 [37, 42-44]. Detailed analysis of $\mathrm{S}$ protein indicates longer capping loop (responsible for electrostatic interaction) and greater protein-protein contact result in the enhanced 
binding capability of SARS-CoV-2 $(-15.7 \mathrm{kcal} / \mathrm{mol})$ in comparison to SARS-CoV $(-14.1 \mathrm{kcal} / \mathrm{mol})$ [45]. These amino acid substitution and greater protein contact found in the hotspot area of the spike protein may indicate the effect of natural selection in increasing the affinity of the SARSCoV-2 toward human ACE2[46].

Other six substitutions in the amino acid residue 569-655 of the SD segment present in S1 subunit have been discovered. Host range and affinity of RBD are critically determined by six RBD amino acids. Four notable substitutions have been seen in two peptides that were served as antigen in C-terminal in S1subunit (Q560L, S570A, F572T, and S575A) [35, 47].

Very recent work based on the isolate from 11 random patients, observed total 33 mutations out of which 19 were new and not reported before including six mutations in the spike S protein. Further, it showed that these mutations lead more cytopathogenicity and viral load in the Vero-E6 cells. This finding suggests that the virus is capable of varying its pathogenicity and virulence in a short time frame [48].

\section{Presence of polybasic furin cleavage site and $\mathrm{N}$-glycan shielding}

Another unique feature of the SARS-COV-2 genome is the insertion of a polybasic furin cleavage site at the S1/S2 interface of spike protein which is missing in all other SARS/ SARS-CoV [42, 49]. Furin is a proteolytic enzyme that is responsible for the cleavage of basic amino acids. Activation and priming by furin-like proteases are the signatures of several pathogenic viruses [50]. Addition of a polybasic cleavage site helps in the cell-cell fusion without altering the viral entry into the cell [50].

Amino acid alignment-based bioinformatics study of the S glycoprotein of SARS-CoV-2 revealed the insertion of furin cleavage sites in the sequence. Surprisingly, the most closely related bat CoV, RaTG-13 doesn't have the furin cleavage site [51] Since, furin proteases are abundant in the respiratory tract, it is hypothesized that SARS-CoV-2 S glycoprotein is separated upon exit from the epithelial cells and therefore can effectively target different cells and can increase the virulence.

Glycan shielding is a critical feature of SARS-CoV-2 having great importance in the context of vaccine designing. Virus uses glycan shielding strategy to evade the host immune system by masking the spike glycoprotein (S protein) through extensive glycosylation. Thick coating of carbohydrate on highly immunogenic epitope of the virus is a classic example of escaping from the host immune responses [52, 53]. Glycosylation pattern of SARS-CoV and SARS-CoV-2 is different from other RNA virus such as HIV in having greater concentration of $\mathrm{N}$-glycan in comparison to O-glycans [54]. SARS-CoV-2 has 22 speculated glycoprotein sites per promoter on the spike protein out of which 17 have been proved to be already preoccupied [54].

\section{Mechanism of virus invasion in host cell}

The viral proteins that mediates SARS-CoV-2 entry and fusion and replication into host cells share a similar structure with those of SARS-CoV. Sequencing of COVID-19 shows $79.5 \%$ sequence similarity to SARS-CoV, $51.8 \%$ with MERS-CoV, and shares $96 \%$ structural identity across the whole genome to a bat coronavirus $[38,55]$.

\section{Virus attachment and fusion}

SARS-CoV-2 has the conventional coronavirus structure with spike glycoprotein, nucleocapsid protein, envelope glycoprotein, membrane glycoprotein, lipid bilayer, and genomic RNA. The CoV spike (S), which is classified as type I viral fusion protein [56], synthesized as 1300 amino acids containing single-chain precursor followed by folding and trimerization [56], plays pivotal role in viral attachment, fusion, and entry to the host cell. The binding between RBD of the spike protein of the SARS-CoV-2 to host ACE2 receptor (angiotensin-converting enzyme 2), is important for viral entry into the host body similar to SARS-CoV [55].

There are two domains of viral S glycoprotein that recognize a variety of host receptors leading to viral attachment (S1) and fusion (S2) domain to host cell. The spike protein, an anchor machinery, present on the surface of coronavirus as homotrimers protruding from the viral surface mediates its entry into the host cell through receptor binding domain (RBD) in S1 subunit. [57] It is reported in many studies on CoVs that $\mathrm{S}$ is cleaved at the host surface between the $\mathrm{S} 1$ and $\mathrm{S} 2$ subunits before fusion, however they remain noncovalently bounded and this confirmation is considered as closed prefusion conformation. [58-62] Further, host proteases cleave $\mathrm{S}$ protein, at $\mathrm{S} 2$ site, very close and upstream to fusion peptide $[63,64]$ that lead to activation the protein for membrane fusion through irreversible fusion favourable conformational changes [60,61, 65-67]. Virus entry into the host cell is complex and orchestrated between both viral and host cell (Fig. 4).

RBD in S1 of SARS-CoV-2 spike protein strongly binds to human ACE 2 and is a key player of virus host range and cellular tropism. Recent evidences by Cryo-Electron Microscopy have affirmed that SARS-CoV-2 S protein binding affinity to ACE2 is approximately $10-20$ times greater than those of SARS-CoV S protein. [41, 68] The other subunit of $\mathrm{S}$ protein i.e., $\mathrm{S} 2$ is enriched with alpha helices and mediates viral-host cell membrane fusion by two tandem domains naming heptads repeats 1 (HR1) and 2 (HR2). The fusion domain contains a fusion peptide composed of 15-25 


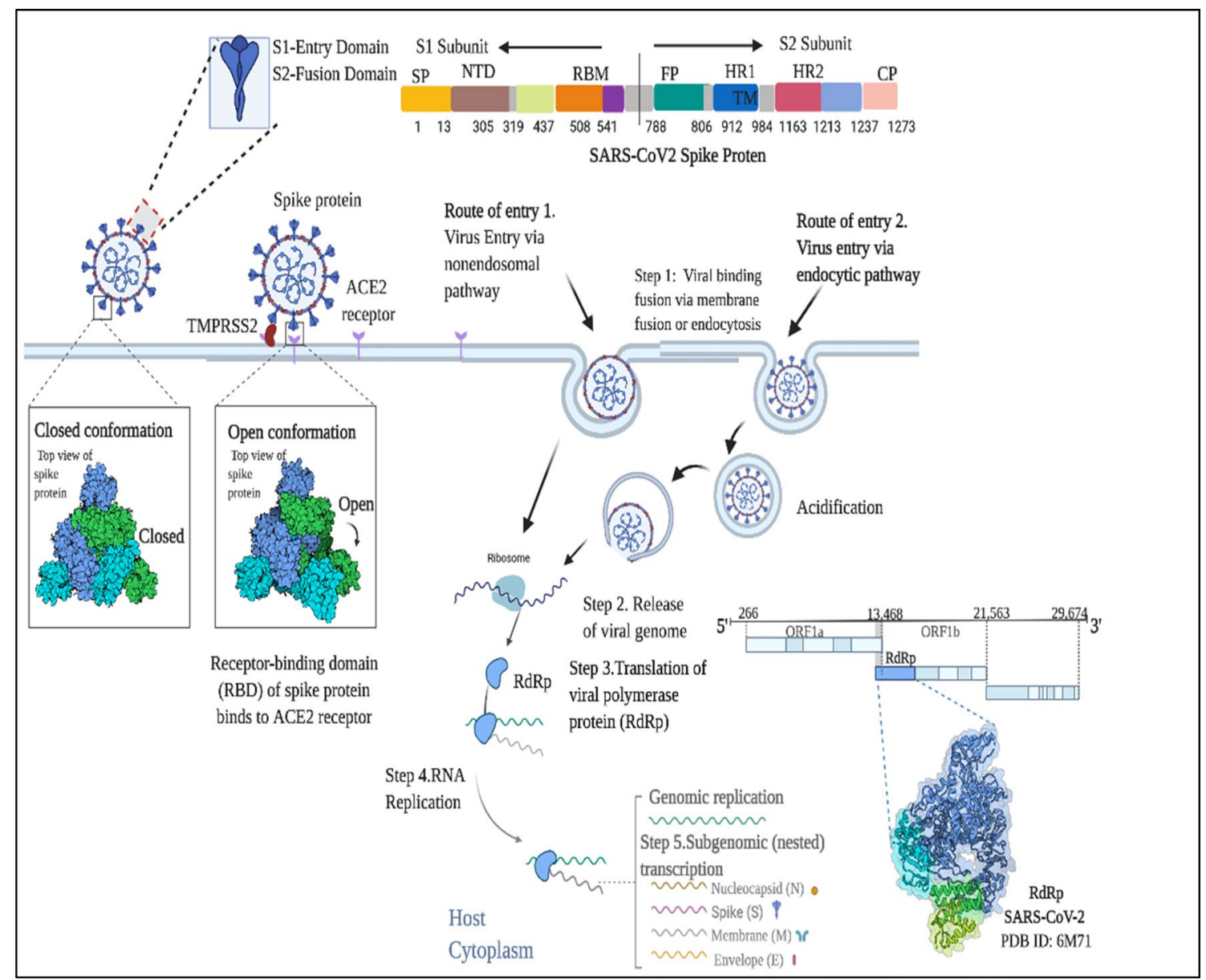

Fig. 4 SARS-CoV-2 Spike protein conformation, entry, fusion and replication. 1 SARS-CoV-2 interacts with host's ACE2 receptors and transmembrane protease serine 2 protein (TMPRSS2) through the spike protein. 2 It is followed by two entry pathways either A. nonendosomal or B. endocytic pathway or both to enter the host cell. 3 .

hydrophobic amino acids. There are two distinct structural conformations of spike protein, before and post fusion which indicates the presence of some triggering mechanism for transition of confirmation.

The second step of viral infection is fusion with the host cellular membrane. Based on structure and function viral fusion proteins are classified into three types (I, II, and III). $[69,70]$ Based on structural features of fusion domain and requirement of protease cleavage to form fusogenic conformation and presence of HR1 and HR2 to form 6-HB, the coronavirus $\mathrm{S}$ protein is classified as class I fusion protein [56]. Fusion machinery, S2, is enriched with alpha helices and mediates viral-cell membrane fusion with the help of two tandem domains naming heptads repeats 1 (HR1) and 2 (HR2) and S2 subunits of SARS-CoV-2 and SARS-CoV shows $88 \%$ sequence identity. HR 1 and HR2 domain of S2 subunit interact with each other that lead to the formation of 6-helix bundle (6-HB) fusion core, which brings viral and
Soon after its entry into host cell, it releases its genome and overtake protein synthesis machinery of host cell and start the translation of RdRp 4 Afterward SARS-CoV-2 replication and transcription are catalyzed by RdRp

host cellular membranes in close proximity for fusion and subsequently leads to the entry of virus in host cells. Four conformational changes happen throughout fusion process (1) Pre-fusion structural conformations (2) pre-fusion metastable conformation (3) pre hair-pin confirmation (4) post fusion stable state, which indicates the presence of some triggering mechanism for transition of confirmation. It is reported in many studies on CoVs that $\mathrm{S}$ protein is cleaved at host surface with protease between the $\mathrm{S} 1$ and $\mathrm{S} 2$ subunits before fusion however, they remain non-covalently bounded and this confirmation is considered as closed metastable prefusion conformation. [56, 59-64] Host proteases cleave $\mathrm{S}$ protein, at $\mathrm{S} 2{ }^{\prime}$, very close and upstream to fusion peptide $[64,65]$ that lead the activation of the protein for membrane insertion through pre-hairpin intermediate state an irreversible fusion favourable conformation [59, 62, 63, $66,67]$. A recent study demonstrates that priming of SARSCoV-2 $\mathrm{S}$ proteins by host cell serine protease TMPRSS 2 and 
endosomal cysteine proteases $\mathrm{CatB} / \mathrm{L}$, vital for viral entry into host cells, mediate through $\mathrm{S}$ protein cleavage at $\mathrm{S} 2$ ' site at S1/S2 interface. [71] After insertion of the FP domain, the HR1 regions rearranged to form coiled trimer and facilitate the binding hydrophobic grooves with three HR2 regions antiparallelly [72]. This rearrangement of HR1 and HR2 forms fusion core 6-HB, which leads to viral and host cell membranes into close proximity for fusion and forms the last stable post-fusion state. The last step of fusion process happens through two stages hemi-fusion stage and pore formation. [73] In a nutshell, virus entry into the host cell is complex and orchestrated between both viral and host cell. Presence and availability proteases involve in priming on target cells play a key role in determining whether CoVs penetrate inside cells through the plasma membrane or endocytosis pathway.

\section{Replication}

Replication machinery has a conserved organization at $5^{\prime}$ end (including nonstructural protein) and $3^{\prime}$ end (including structural protein). The viral replication is initiated when $\mathrm{S}$ protein binds to the ACE2 receptor inducing a conformational change which results in the endocytosis of the virus causing the release of viral ssRNA genome into the host cytoplasm [67].

The corona virus replication process could be divided into three parts: (1) translation of viral genome (ssRNA) to make necessary protein for genome synthesis (2) Simultaneous transcription and translation process (3) Assembly of viral genome and protein (Fig. 4). The SARS-CoV-2 replicase gene present on the $5^{\prime}$ end make around $2 / 3$ of the genome and consists of two 2 ORF, ORF1 and ORF 2 which further code for two co- terminal polyproteins ppla and pp1a respectively $[29,74]$. For the expression of these two polyproteins, slippery sequence (5-UUUAAAC-3) and RNA pseudoknot is essential for ribosomal frameshifting from the rep1a reading frame into rep1b ORF. These polyproteins are subsequently cleaved in distinctive nonstructural protein (nsp). Cleavage of giant polyprotein mainly done by two proteases, papain-like (PLpro or nsp3) and chymotrypsin like (3CLpro or nsp5) into $16 \mathrm{nsp}$. ORF1a encode nsp1 to nsp11 and ORF1b encodes nsp12 to nsp16. The 3' part of the genome encode for 13 ORF's which include 4 structural proteins and 13 accessory proteins.

The second step is the organization of nsp 7, 8, and 9 at 3 'end of genomic RNA to form membrane-associated replicase-transcriptase complex (RTC) where nps8 primase initiate RNA synthesis that finally leads to change in confirmation of 3'RNA (BSL to PK). This conformation change recognized by RdRp and helicase (nsp13) and other related factors like processing (nsp7 and nsp8), proofreading (nps10 and nps14)) and allow the synthesis of negative stranded RNA to replication and translation of genomic and subgenomic RNA. Further, this negative strand RNA can take two pathways 1. Replication into genomic positive sense RNA or 2. Discontinuous transcription into several subgenomic mRNA that can be translated into different proteins [75].

In discontinuous transcription small subgenomic RNA are transcribed through premature termination during the synthesis of the negative-strand RNAs when preceding viral gene, TRS-B, jump and bind to the TRS-L of parent RNA. Long distant interaction TRS-B of preceding gene and $5^{\prime}$ TRS-L of parent RNA is mediated through RNA-protein complex as complex bring them in close proximity. [76-78]. This whole process of replication happens in DMV (double membrane vesicle) and CM (convoluted membrane). SARS-CoV electron tomography analysis demonstrated that it forms a unique reticulovesicular network with which both viral replicase subunits and ssRNA were associated [79].

Recent studies reveal that DMVs are originated from ER and nps4 and nps6 play a key role in DMVs formation by inserting their hydrophobic transmembrane domain into ER. Further after replication of genomic and subgenomic RNA in RTC complex start translation of accessory proteins, structural (S, E, M proteins), and nonstructural proteins.

In the third step assembly of virion takes place. After the synthesis of these proteins, they are inserted into the endoplasmic reticulum, then move through the secretory pathway (ER-Golgi intermediate compartment [80, 81]. In this compartment, the viral genome is encapsulated by $\mathrm{N}$ protein forming the mature virion containing vesicles [82]. Further, virions packed in the vesicle are carried to the cell surface and delivered by membrane fusion and exocytosis. How transportation of virion happens exactly, not clear yet. Either it happens through large cargo from Golgi or virus follow different, novel exit pathway.

\section{Cellular tropism}

Both SARS-CoV and SARS-CoV-2 known to use human ACE2 receptor to take entry inside the cell [83]. SARSCoV-2 mainly affects respiratory tract however there are several evidences that show broader cell tropism. Clinical manifestations of SARS-CoV-2 have been well defined and genome of SARS-CoV-2 is fully sequenced. However, much of the cellular tropism and its manifestation is still unclear and limited data on tissue and cellular tropism are available as of now. ACE2 receptors expression was significantly seen in alveolar, type II epithelial cells, heart, kidney, brain and gastrointestinal tract (especially in small and large intestines). The single cell RNA sequencing studies showed the presence of ACE2 mRNA in different cells of various organs such as lung epithelial cells, myocytes, kidney tubular cells, 
oesophageal epithelial, urothelial cells [84-86]. Greater binding affinity with ACE2 might facilitate virus entry into pulmonary cells leading to higher transmission among people through various direct and indirect contacts with the patients [44]. The robust replicative property of coronavirus in bronchial as well as alveolar epithelium also describes the higher transmissibility of SARS-CoV- 2 as compared to other CoVs. SARS-CoV-2 and SARS-CoV have shown significant replication in various cell lines that manifest their abilities to cause lower respiratory tract infection. Reports have shown replication competence and cellular tropism of SARS-CoV-2 in respiratory tract and extra pulmonary cells. SARS-CoV shown significant replication levels in both Calu3 (pulmonary cells) and Caco2 (intestinal cell) which indicated lower respiratory tract and gastrointestinal infection in COVID- 19 patients [87].

\section{Cardiovascular system}

Cardiovascular manifestations are also one of the prominent consequences due to SARS-CoV-2 infection. This includes various cardiac injuries, stroke, coronary arterial ischemia, pulmonary embolism, arterial thrombosis etc. [88]. In a cohort study consisting of 2 groups (29 patients) infected with SARS-CoV-2, 30-fold increase in Kawasaki like disease were observed. [89] SARS-CoV-2 infection seems to be correlated with higher incidences of cardiac dysfunction and macrophage activation syndrome. [89].

\section{Endothelial cell}

Recent studies shown viral infection and inflammation in endothelial cell in COVID-19 infected patient due to presence of same ACE2 receptor on the surface of endothelial cells. Other than this, endothelial dysfunction has also been seen because of the recruitment of different immune cells by various direct and indirect infection caused by SARS-CoV-2, which is associated with cell death and multiple organ failure. [90].

\section{Gastrointestinal tract and liver}

Evidence from several studies indicated that coronavirus has a tropism to the gastrointestinal tract due to the presence of ACE2 receptor. Different cohort studies showed diarrhoea vomiting and other gastrointestinal problems [91-96]. Liver injury was also reported in the blood test reports of COVID-19 patients [97]. Elevated levels of alanine aminotransferase (ALT) and aspartate aminotransferase (AST) were also detected in cohort studies of infected patients [91, 92]. There was abnormal elevation of bilirubin during the infection. However, there was no severe damage observed in liver function, but the patients having severe viral infection seems to have higher level of liver injury. Similar infection of colorectal carcinoma epithelial cell line shown replication of virus in gastrointestinal tract that hints possibility of oralfaecal transmission. These multiple routes of transmission might explain the rapid spread of COVID-19 worldwide.

\section{Kidney}

Cellular tropism for kidney was observed even in the patients who do not have any history of chronic renal disease. mRNA sequencing studies revealed that ACE2, TMPRSS, Cathepsin genes are present in kidney cells that facilitate the entry and infection of SARS-CoV-2 causing various kidney injuries [98]. Chronic kidney injuries are one of the strongest risk factors for COVID-19 related death [99, 100]. In the cohort study consisting post-mortem report of 63 patients, out of this SARS-CoV-2 RNA was found in $60 \%$ of the patients with kidney injuries. Renal tropism also shown to be associated with disease severity and kidney injury that leads to premature death [101].

\section{Brain}

SARS-CoV-2 also infects extra pulmonary tissue including CNS and PNS, mechanism of which is still not known. It is hypothesized that virus crosses the blood brain barrier to invade the brain that leads to various neurological manifestations including headache, dizziness, seizures, loss of consciousness. Reports have shown that SARS-CoV-2 can also cause viral encephalitis, meningitis, encephalopathy etc. Mao et. al [102] shown ischemic and haemorrhagic stroke as one of the neurological manifestations seen in $3 \%$ of infected patients.

\section{Eyes}

There are evidence showing conjunctival epithelium and conducting airways as potential portal of infection for SARS-CoV-2. Infection in conjunctiva suggests eye as additional route of infection [103].

\section{Immunomodulation by SARS CoV-2}

Innate immunity presents the first barrier for virus invasion. Pattern recognizing receptor (PRR) recognizes the molecular patterns associated with the virus and initiate a cascade of downstream signaling to release a burst of cytokines known as cytokine storm (Fig. 5). This include both $\mathrm{Th}_{1}$ and $\mathrm{Th}_{2}$ associated cytokines including IL1, IFN $\gamma$, IL10 etc. [104]. IL6 which is known to play an important antiviral role in case of influenza and herpex simplex virus (HSV) $[105,106]$ and its higher level is 


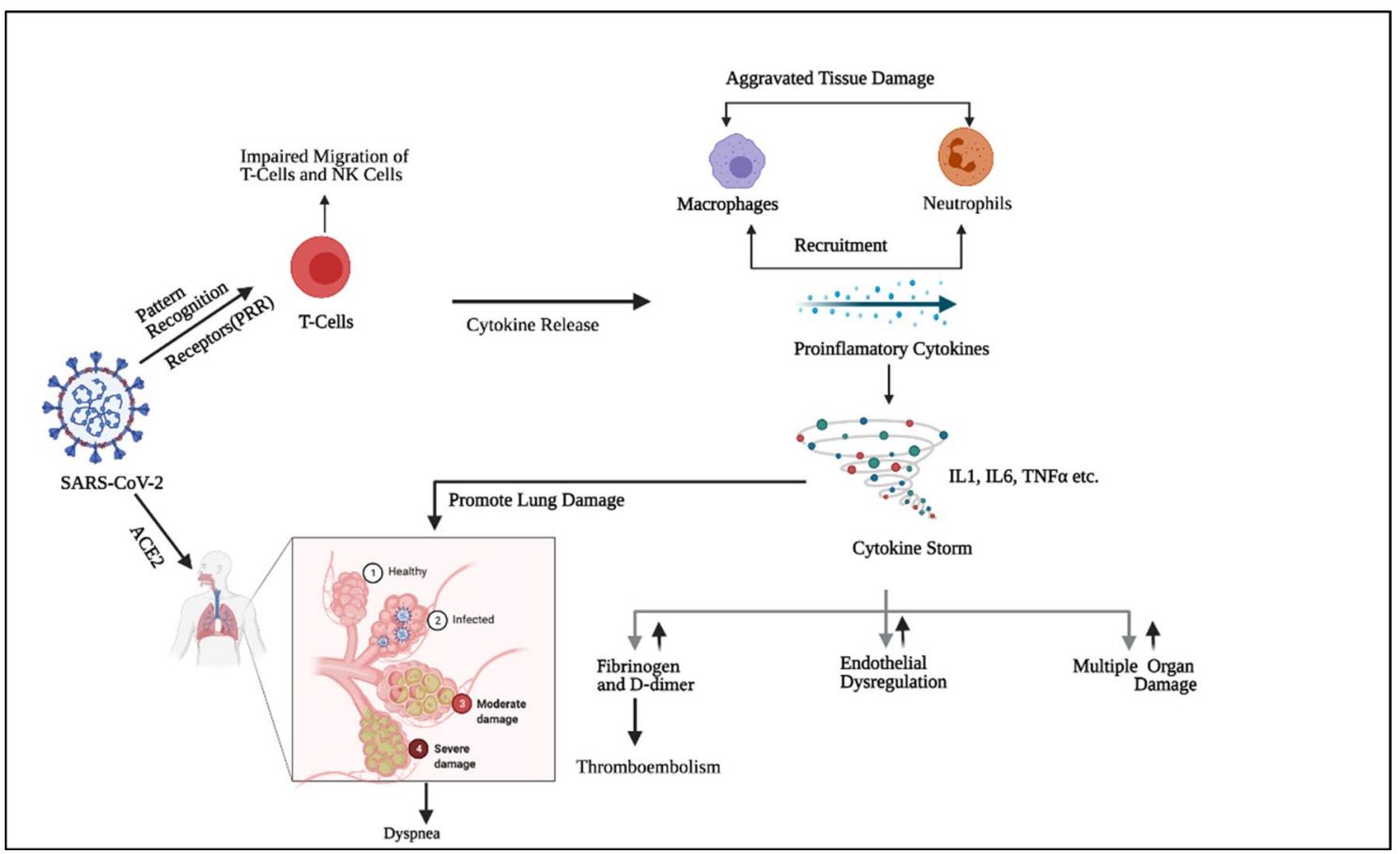

Fig. 5 Overview of immunological aspect of COVID-19 indicating the viral induced immune modulation in the infected host tissues. SARS-CoV-2 is recognised by the pattern recognising receptors by the $\mathrm{T}$ cells which in turn initiates a cascade of events particularly

correlated with the severe progression of the disease and mortality in SARS-CoV and SARS-CoV-2. [107, 108] IL6 can be induced directly or indirectly by SARS. Studies found out that indirect stimulation happens when the virus bind to the toll like receptor 4 (TLR4) and induces IL6 expression through NF- $\mathrm{\kappa B}$ pathway [109]. Direct stimulation of IL6 occurs when structural protein ( $\mathrm{N}$ protein) of SARS-CoV bind to the NF- $\mathrm{KB}$ regulatory portion in the promoter region of IL6 [110]. IFN $\gamma 1$ pre-injection or early presence can limit or stop the virus associated damage with much more potency than in SARS-CoV [111]. Adaptive immune response in viral infected patient are drastically affected as helper $T$ cells and cytotoxic $T$ cells are significantly reduced in the peripheral circulation in moderate and severe cases of COVID-19 [112]. Number of CD8 memory $\mathrm{T}$ cells exceeds the CD4 memory T cells in the SARS-CoV survivor and virus specific $\mathrm{T}$ cells present in the blood for at least 6-11 years [113]. IFN $\gamma$ and TNF $\alpha$ that are upregulated in the infected patient are responsible for the retention and binding of $\mathrm{T}$ cells to the epithelium in the lymphoid organs that may result in overall reduction in peripheral blood circulation. [114] Lavage fluid collected from the COVID-19 patients showed the clonal expansion of $\mathrm{CD} 8$ cells suggesting that $\mathrm{T}$ cell migration to the infected site that results in the overall lower peripheral counts. [115]. cytokine storm, recruitment of inflammatory cells etc., ultimately resulting in multiple organ damage and the development of symptoms that are associated with the progression of COVID-19 disease

\section{Immuno-pathogenesis}

A study of 99 hospitalized patients in china showed that $12 \%$ had thrombocytopenia, $36 \%$ had elevated D dimer and proinflammatory cytokines, $5 \%$ show increase prothrombin and four others suffered from septic shock [116]. As already discussed, SARS-CoV-2 induced a burst of proinflammatory cytokines in the infected site. The higher level of these cytokines in the serum may be correlated with the lung lesion as these cytokines promoted the massive migration of immune cells to the infected site (Fig. 5). Also, type II alveolar cells of the lung express high level of ACE2 receptor, thus lung is one of the most susceptible organ to viral attack [117]. These lung lesion may be correlated with the dyspnea, a common symptom associated with COVID-19 [118]. Lung Natural killer (NK) cells doesn't possess the ACE2 receptor, exhibit $\mathrm{CD}_{16}{ }^{+} \mathrm{KIR}^{+}$phenotype thus virus can't directly target these cells but studies found that after infection $\mathrm{CD} 16^{+} \mathrm{NK}$ cell significantly decreased in the peripheral blood suggesting defective migration or maturation process of NK cells [119, 120]. Thrombocytopenia is also normally observed symptom in the patients suffering from COVID19. One hypothesis could be that virus may bind to CD13, a marker present on bone marrow cells and platelets and then induces apoptosis of the megakaryocytes thus resulting in decrease number of platelets [121]. Another hypothesis is 
that SARS-CoV-2 bind the liver cells via ACE2 receptor and induces its damage. Liver cells produce thrombopoietin required for the differentiation and maturation of megarkaryocytes in to the platelets $[122,123]$. Also, lung damage induced by the proinflammatory cytokines reduces the capillary bed in the lung which may result in lower pulmonary recirculation and ultimate result is thrombocytopenia. [124, 125]. Further, increase in proinflammatory cytokine particularly IL6 induces fibrinogen and D dimer which may indicate a direct link between cytokine storm and procoagulation/ thromboembolism in the virus infected persons [126-128].

Dysgensia (loss of taste) and Hyposmia (loss of smell) are an early indicator of SARS-CoV-2 infection [129]. Salivary gland and neural cells of olfactory epithelium express ACE2 receptors thus serves as a target of SARS-CoV-2. Infected salivary glands may produce less quantity and quality of saliva, thus resulting in dysgensia. [130] Damage to neuronal cells of olfactory epithelium, expressing high amount of ACE2 receptor may be a reason behind the partial loss of smell associated with the viral infection. [131].

\section{Conclusion and future direction}

This short review provides brief overview of available information of SARS-COV-2 origin, infectivity, biology, brief molecular insight of disease pathogenesis and progression. It also includes concise description of peculiar mutations, genome organization, cell tropism and immunomodulation/immunopathogenesis caused by SARSCoV-2. Current pandemic caused by SARS-CoV-2 is the deadliest pandemic of twenty first century that took whole world on storm. Despite of our best effort and frenetic search of therapeutic we are not able to find the cure of COVID-19 even after more than one year since outbreak. Since last century we have witnessed several virus outbreaks i.e., Swine Flu, Ebola, Zika and so on. Even after much efforts pathogenic virus outbreaks keep happening and huge scientific advancement is not enough to combat such pandemics. The disease keeps spreading and taking toll on lives and economy despite of huge efforts and there are emergence of second and third wave across the globe. Researchers are unfolding mysteries around corona virus every day in all dimensions i.e., infectivity, clinical manifestation, drug trials and failures and vaccine development. Coronaviruses emergence is very rapid, repetitive and unpredictable. However, disease pathogenesis and involvement of several human receptors/proteins such ACE2, Cathepsine, and viral protein such as PLpro, CLpro and other accessary protein involved in disease progression are explored well now and can provides better insight for screening of new lead molecules for antiviral drug development. But, we need integrated approach involving computational biology, genome analysis, immunology, proteomics studies, and systems biology along with various animal models for in depth information of disease progression and manifestation. To be better prepared to mitigate this kind of pandemic in future, it is very necessary to have multidisciplinary international consortium including virologist, molecular biologist, pathophysiologist, chemist, statistician and clinician. Considering the threat imposed by SARS-CoV-2, there is dire need to take virus research at deeper level for better understanding of pathogenesis from molecular to clinical level and to develop the advance therapeutic strategies to tackle COVID-19 like infection in future.

Current outbreak not only necessitates development of the broad spectrum antiviral drug but also the more robust, sustainable and responsive global public healthcare preparedness than ever. SARS-CoV-2 is far more infectious and widespread than earlier CoVs. There are challenges not only associated with virus but with patients as it imposes several issues like wide range of symptoms, severity and clinical manifestations. The disease need to be understood on various parameters such as heterogeneity in infected population, genetic makeup, co-morbidity/ pre-existing medication for clear and comprehensive understanding for effective treatment. Immune- triggered response are worsening the treatment outcome and hampering the disease understanding. Drug repurposing has surfaced as life and time saver, cost effective alternative during COVID-19 pandemic. Currently, repurposed drugs are used to treat critical patients. However, there are challenges associated with drug repurposing such as dose optimization and dose associated toxicity that need to be addressed carefully. Virus affect the host immune response as well as organ function and repurposed drug can cause adverse pharmacological effect on ailing patients. Another important aspect which should be taken into consideration while using repurposed is pharmacogenomics which is overlooked due to extenuating situation to treat the critical patients. Pharmacogenomics is key parameter to establish for long term efficacy and safety of the drugs.

More so, zoonotic origin virus and pathogens outbreaks are inevitable and likely to continue in future so concerted and cohesive efforts considering all aspect are required to minimise the health care burden and death toll in future.

Acknowledgements We would like to thank Director, Institute of Nuclear Medicine and Applied Sciences (INMAS), for his continuous support. This work was funded by Defence Research Development Organization, India, Project No. S\&T/18-19/INM-323. Images are created using Biorender.com

Authors Contribution The named two authors with equal contribution participated equally in designing the study, writing, and editing of the manuscript. 


\section{Compliance with ethical standards}

Conflict of interest The authors declare no competing interests.

\section{References}

1. Gorbalenya AE, Baker SC, Baric RS, de Groot RJ, Drosten C, Gulyaeva AA, Haagmans BL, Lauber C, Leontovich AM, Neuman BW, Penzar D, Perlman S, Poon Samborskiy Sidorov Sola Ziebuhr LLMDIAIJ (2020) The species severe acute respiratory syndrome related coronavirus: classifying 2019-nCoV and naming it SARS-CoV-2. Nat Microbiol 5:536-544

2. Krishnan A, Hamilton JP, Alqahtani SA, Woreta TA (2021) COVID-19: an overview and a clinical update. World J Clin Cases 9(1):8-23

3. McGill AR, Kahlil R, Dutta R, Green R, Howell M, Mohapatra S, Mohapatra SS (2021) SARS-CoV-2 immuno-pathogenesis and potential for diverse vaccines and therapies: opportunities and challenges. Infect Disease Rep 13(1):102-125

4. Tang Q, Song Y, Shi M, Cheng Y, Zhang W, Xia XQ (2015) Inferring the hosts of corona-virus using dual statistical models based on nucleotide composition. Sci Rep 5:17155

5. Samavati L, Uhal BD (2020) ACE2, much more than just a receptor for SARS-COV-2. Front Cell Infect Microbiol 10:317

6. Su S, Wong G, Shi W, Liu J, Lai AC, Zhou J, Liu W, Bi Y, Gao GF (2016) Epidemiology, genetic recombination, and pathogenesis of coronaviruses. Trends Microbiol 24(6):490-502

7. Zhu N, Zhang D, Wang W, Li X, Yang B, Song J, Zhao X, Huang B, Shi W, Lu R, Niu P, Zhan F (2020) A novel coronavirus from patients with pneumonia in China, 2019. New Engl J Med. https://doi.org/10.1056/NEJMoa2001017

8. Holshue ML, DeBolt C, Lindquist S, Lofy KH, Wiesman J, Bruce H, Spitters C, Ericson K, Wilkerson S, Tural A, Diaz G, Cohn A, Fox L, Patel A, Gerber SI, Kim L, Tong S, Lu X, Lindstrom S, Pallansch MA, Weldon WC, Biggs HM, Uyeki TM, Pillai SK, Washington State 2019-nCoV Case Investigation Team (2020) First Case of 2019 novel coronavirus in the United States. New Engl J Med 382(10):929-936

9. Rothe C, Schunk M, Sothmann P, Bretzel G, Froeschl G, Wallrauch C, Zimmer T, Thiel V, Janke C, Guggemos W, Seilmaier M, Drosten C, Vollmar P, Zwirglmaier K, Zange S, Wölfel R, Hoelscher M (2020) Transmission of 2019-nCoV infection from an asymptomatic contact in Germany. N Engl J Med 382(10):970-971

10. Li Q, Guan X, Wu P, Wang X, Zhou L, Tong Y, Ren R, Leung K, Lau E, Wong JY, Xing X, Xiang N, Wu Y, Li C, Chen Q, Li D, Liu T, Zhao J, Liu M, Tu W, Chen C, Jin L, Yang R, Wang Q, Zhou S, Wang R, Liu H, Luo Y, Liu Y, Shao G, Li H, Tao Z, Yang Y, Deng Z, Shi G, Lam TT, Wu JT, Gao GF, Cowling BJ, Yang B, Leung GM, Feng Z (2020) Early transmission dynamics in wuhan, china, of novel coronavirus-infected pneumonia. $\mathrm{N}$ Engl J Med 382(13):1199-1207

11. Zhu N, Zhang D, Wang W, Li X, Yang B, Song J, Zhao X, Huang B, Shi W, Lu R, Niu P, Zhan F, Ma X, Wang D, Xu W, WU G, Gao GF, Tan W, for the China Novel Coronavirus Investigating and Research Team (2020) A novel coronavirus from patients with pneumonia in China, 2019. New Engl J Med. https://doi. org/10.1056/NEJMoa2001017

12. Ren LL, Wang YM, Wu ZQ, Xiang ZC, Guo L, Xu T, Jiang YZ, Xiong Y, Li YJ, Li XW, Li H, Fan GH, Gu XY, Xiao Y, Gao H, Xu JY, Yang F, Wang XM, Wu C, Chen L, Liu YW, Liu B, Yang J, Wang XR, Dong J, Li L, Huang CL, Zhao JP, Hu Y, Cheng ZS, Liu LL, Qian ZH, Qin C, Jin Q, Cao B, Wang JW (2020)
Identification of a novel coronavirus causing severe pneumonia in human: a descriptive study. Chin Med J 133(9):1015-1024

13. Liu K, Fang YY, Deng Y, Liu W, Wang MF, Ma JP, Xiao W, Wang YN, Zhoung MH, Li CH, Li GC, Liu HG (2020) Clinical characteristics of novel coronavirus cases in tertiary hospitals in Hubei Province. Chin Med J. https://doi.org/10.1097/CM9.00000 00000000744

14. Wang D, Hu B, Hu C, Zhu F, Liu X, Zhang J, Wang B, Xiang H, Cheng Z, Xiong Y, Zhao Y, Li Y, Wang X, Peng Z (2020) Clinical characteristics of 138 hospitalized patients with 2019 novel coronavirus-infected pneumonia in Wuhan China. JAMA 323(11):1061-1069. https://doi.org/10.1001/jama.2020.1585

15. Wu Z, McGoogan JM (2020) Characteristics of and important lessons from the coronavirus disease 2019 (COVID-19) outbreak in China: summary of a report of 72,314 cases from the Chinese Center for Disease Control and Prevention. JAMA 323(13):1239-1242

16. Wenham C, Smith J, Morgan R (2020) COVID-19: the gendered impacts of the outbreak. Lancet. https://doi.org/10.1016/S01406736(20)30526-2

17. Jin JM, Bai P, He W, Wu F, Liu XF, Han DM, Liu S, Yang JK (2020) Gender differences in patients with COVID-19: focus on severity and mortality. Front Public Health 8:152

18. Li Q, Guan X, Wu P, Wang X, Zhou L, Tong Y, Ren R, Leung K, Lau E, Wong JY, Xing X, Xiang N, Wu Y, Li C, Chen Q, Li D, Liu T, Zhao J, Liu M, Tu W, Chen C, Jin L, Yang R, Wang Q, Zhou S, Wang R, Liu H, Luo Y, Liu Y, Shao G, Li H, Tao Z, Yang Y, Deng Z, Shi G, Lam TT, Wu JT, Gao GF, Cowling BJ, Yang B, Leung GM, Feng Z (2020) Early transmission dynamics in Wuhan, China, of novel coronavirus-infected pneumonia. N Engl J Med 382:1199-1207

19. Yang Y, Lu Q, Liu M, Wang Y, Zhang A, Jalali N, Dean N, Longini I, Halloran ME, Xu B, Zhang X, Wang L, Liu W, Fang L (2020) Epidemiological and clinical features of the 2019 novel coronavirus outbreak in China. MedRxiv. https://doi.org/10. 1101/2020.02.10.20021675

20. Linton NM, Kobayashi T, Yang Y, Hayashi K, Akhmetzhanov AR, Jung SM, Yuan B, Kinoshita R, Nishiura H (2020) Incubation period and other epidemiological characteristics of 2019 novel coronavirus infections with right truncation: a statistical analysis of publicly available case data. J Clin Med 9(2):538

21. Bi Q, Wu Y, Mei S, Ye C, Zou X, Zhang Z, Liu X, Wei L, Truelove SA, Zhang T, Gao W, Cheng C, Tang X, Wu X, Wu Y, Sun B, Huang S, Sun Y, Zhang J, Ma T et al (2020) Epidemiology and transmission of COVID-19 in 391 cases and 1286 of their close contacts in Shenzhen, China: a retrospective cohort study. Lancet Infect Dis 20(8):911-919

22. Guan WJ, Ni ZY, Hu Y, Liang WH, Ou CQ, He JX, Shan H, Lei CL, Hui DS, Du B, Li LJ, Zeng G, Yuen KY, Chen RC, Tang CL, Wang T, Chen PY, Xiang J, Li SY, Wang JL, Liang ZJ, Peng YX, Wei L, Liu Y, Hu YH, Peng P, Wang JM, Liu JY, Chen Z, Li G, Zheng ZJ, Oui SQ, Luo J, Ye CJ, Zhu SY, Zhong NS (2020) Clinical characteristics of 2019 novel coronavirus infection in China. New Engl J Med. https://doi.org/10.1056/NEJMoa2002 032

23. Huang C, Wang Y, Li X, Ren L, Zhao J, Hu Y, Zhang L, Fan G, Xu J, Gu X, Cheng Z, Yu T, Xia J, Wei Y, Wu W, Xie X, Yin W, Li H, Liu M, Xiao Y, Gao H, Guo L, Xie J, Wang G, Jiang R, Gao Z, Jin Z, Lin Q, Wang J, Cao B (2020) Clinical features of patients infected with 2019 novel coronavirus in Wuhan, China. Lancet 395(10223):497-506

24. Zhu N, Zhang D, Wang W, Li X, Yang B, Song J, Zhao X, Huang B, Shi W, Lu R, Niu P, Zhan F, Ma X, Wang D, Xu W, Wu G, Gao GF, Tan W, China Novel Coronavirus Investigating and Research Team (2020) A novel coronavirus from patients with pneumonia in China, 2019. New Engl J Med 382(8):727-733 
25. Zhou P, Yang XL, Wang XG, Hu B, Zhang L, Zhang W, Si HR, Zhu Y, Li B, Huang CL, Chen HD, Chen J, Luo Y, Guo H, Jiang RD, Liu MQ, Chen Y, Shen XR, Wang X, Zheng XS, Zhao K, Chen QJ, Deng F, Liu LL, Yan B, Zhan FX, Wang YY, Xiao G, Shi ZL (2020) Discovery of a novel coronavirus associated with the recent pneumonia outbreak in humans and its potential bat origin. Nature. https://doi.org/10.1038/s41586-020-2012-7

26. Sabir JS, Lam TTY, Ahmed MM, Li L, Shen Y, Abo-Aba SE, Qureshi MI, Zeid MA, Zhang Y, Khiyami MA, Alharbi NS, Hajrah NH, Sabir MJ, Mutwakil MH, Kabli SA, Alsulaimany FA, Obaid AY, Zhou B, Smith DK, Holmes EC, Zhu H, Guan Y (2016) Co-circulation of three camel coronavirus species and recombination of MERS-CoVs in Saudi Arabia. Science 351(6268):81-84

27. Lin XD, Wang W, Hao ZY, Wang ZX, Guo WP, Guan XQ, Wang MR, Wang HW, Zhou RH, Li MH, Tang GP, Wu J, Holmes EC, Zhang YZ (2017) Extensive diversity of coronaviruses in bats from China. Virology 507:1-10

28. Chen Y, Liu Q, Guo D (2020) Emerging coronaviruses: genome structure, replication, and pathogenesis. J Med Virol 92(4):418-423

29. Chan JF, Kok KH, Zhu Z, Chu H, To KK, Yuan S, Yuen K (2020) Genomic characterization of the 2019 novel human-pathogenic coronavirus isolated from a patient with atypical pneumonia after visiting Wuhan. Emerg Microbes Infect 9(1):221-236

30. Zhou P, Yang X, Wang X, Hu B, Zhang L, Zhang W, Si H, Zhu Y, Li B, Huang C, Chen H, Chen J, Luo Y, Guo H, Jiang R, Liu M, Chen Y, Shen X, Wang X, Zhang X, Zhao K, Chen Q, Deng F, Liu L, Yan B, Zhan F, Wang Y, Xiao G, Shi Z (2020) A pneumonia outbreak associated with a new coronavirus of probable bat origin. Nature 579:270-273

31. Mousavizadeh L, Ghasemi S (2020) Genotype and phenotype of COVID-19: their roles in pathogenesis. J Microbiol Immunol Infect. https://doi.org/10.1016/j.jmii.2020.03.022

32. Lokugamage KG, Hage A, Schindewolf C, Rajsbaum R, Menachery VD (2020) SARS-CoV-2 is sensitive to type I interferon pretreatment. J Virol 42:749

33. Khailany RA, Safdar M, Ozaslan M (2020) Genomic characterization of a novel SARS-CoV-2. Gene Rep 19:100682

34. Guo YR, Cao QD, Hong ZS, Tan YY, Chen SD, Jin HJ, Tan KS, Wang DY, Yan Y (2020) The origin, transmission and clinical therapies on coronavirus disease 2019 (COVID-19) outbreak-an update on the status. Mil Med Res 7(1):1-10

35. Wu A, Peng Y, Huang B, Ding X, Wang X, Niu P, Meng J, Zhu Z, Zhang Z, Wang J, Sheng J, Quan L, Xia Z, Tan W, Cheng G, Jiang T (2020) Genome composition and divergence of the novel coronavirus (2019-nCoV) originating in China. Cell Host Microbe 27:325

36. Wan Y, Shang J, Graham R, Baric RS, Li F (2020) Receptor recognition of novel corona virus from Wuhan: an analysis based on decade long structural studies of SARS coronavirus. J Virol 2020(4):1-5

37. Tai W, He L, Zhang X, Pu J, Voronin D, Jiang S, Zhou Y, Du L (2020) Characterization of the receptor-binding domain (RBD) of 2019 novel coronavirus: implication for development of RBD protein as a viral attachment inhibitor and vaccine. Cell Mol Immunol 17(6):613-620

38. Lu R, Zhao X, Li J, Niu P, Yang B, Wu H, Wang W, Song H, Huang B, Zhu N, Bi Y, Ma X, Zhan F, Wang L, Hu T, Zhou H, Hu Z, Zhou WZ, Zhao L, Chen J, Meng Y, Wang J, Lin Y, Yuan J, Xie Z, Ma J, Liu W, Wang D, Xu W, Holmes EC, Gao GF, Wu G, Chen W, Shi W, Tan W (2020) Genomic characterisation and epidemiology of 2019 novel coronavirus: implications for virus origins and receptor binding. Lancet 395(10224):565-574

39. Li F, Li WH, Farzan M, Harrison SC (2005) Structure of SARS coronavirus spike receptor-binding domain complexed with receptor. Science 309:1864-1868. https://doi.org/10.1126/scien ce. 1116480

40. Xia S, Zhu Y, Liu M, Lan Q, Xu W, Wu Y, Ying T, Liu S, Shi Z, Jiang S, Lu L (2020) Fusion mechanism of 2019-nCoV and fusion inhibitors targeting HR1 domain in spike protein. Cell Mol Immunol 17:1-3

41. Towler P, Staker B, Prasad SG, Menon S, Tang J, Parsons T, Ryan D, Fisher M, Williams D, Dales NA, Patane MA, Pantoliano MW (2004) ACE2 X-ray structures reveal a large hingebending motion important for inhibitor binding and catalysis. J Biol Chem 279(17):17996-18007

42. Wan Y, Shang J, Graham R, Baric RS, Li F (2020) Receptor recognition by the novel coronavirus from Wuhan: an analysis based on decade-long structural studies of SARS coronavirus. J Virol. https://doi.org/10.1128/JVI.00127-20

43. Walls AC, Park YJ, Tortorici MA, Wall A, McGuire AT, Veesler D (2020) Structure, function, and antigenicity of the SARSCoV-2 spike glycoprotein. Cell. https://doi.org/10.1016/j.cell. 2020.02.058

44. Wrapp D, Wang N, Corbett KS, Goldsmith JA, Hsieh CL, Abiona O, Graham BS, McLellan JS (2020) Cryo-EM structure of the 2019-nCoV spike in the prefusion conformation. Science 367(6483):1260-1263

45. Ortega JT, Serrano ML, Pujol FH, Rangel HR (2020) Role of changes in SARS-CoV-2 spike protein in the interaction with the human ACE2 receptor: an in silico analysis. EXCLI J 19:410-417

46. Wang K, Chen W, Zhou Y, Lian J, Zhang Z, Du P, Gong L, Zhang Y, Cui H, Geng J, Wang B, Sun X, Wang C, Yang X, Lin P, Deng Y, Wei D, Yang X, Zhu Y, Zhang K, Zheng Z, Miao J, Guo T, Shi Y, Zhang J, Fu L, Wang Q, Bian H, Zhu P, Chen Z (2020) SARS-CoV-2 invades host cells via a novel route: CD147spike protein. Signal Transduct Target Ther. https://doi.org/10. 1038/s41392-020-00426-x

47. Guo JP, Petric M, Campbell W, McGeer PL (2004) SARS corona virus peptides recognized by antibodies in the sera of convalescent cases. Virology 324(2):251-256

48. Yao HP, Lu X, Chen Q, Xu K, Chen Y, Cheng L, Liu F, Wu Z, Wu H, Jin C, Zheng M, Wu N, Jiang C, LI L (2020) Patientderived mutations impact pathogenicity of SARS-CoV-2 CELLD-20-01124. SSRN Electron J. https://doi.org/10.2139/ssrn. 3578153

49. Andersen KG, Rambaut A, Lipkin WI, Holmes EC, Garry RF (2020) The proximal origin of SARS-CoV-2. Nat Med 26(4):450-452

50. Klenk HD, Garten W (1994) Host cell proteases controlling virus pathogenicity. Trends Microbiol 2(2):39-43

51. Zhang T, Wu Q, Zhang Z (2020) Probable pangolin origin of SARS-CoV-2 associated with the COVID-19 outbreak. Curr Biol. https://doi.org/10.1016/j.cub.2020.03.063

52. Watanabe Y, Allen JD, Wrapp D, McLellan JS, Crispin M (2020) Site-specific glycan analysis of the SARS-CoV-2 spike. Science. https://doi.org/10.1126/science.abb9983

53. Watanabe Y, Berndsen ZT, Raghwani J, Seabright GE, Allen JD, Pybus OG, McLellan JS, Wilson IA, Bowden TA, Ward AB, Crispin M (2020) Vulnerabilities in coronavirus glycan shields despite extensive glycosylation. Nat Commun 11(1):2688

54. Walls AC, Park YJ, Tortorici MA, Wall A, McGuire AT, Veesler D (2020) Structure, function, and antigenicity of the SARSCoV-2 spike glycoprotein. Cell 181(2):281-292

55. Zhou P, Yang X, Wang XG, Hu B, Zhang L, Zhang W, Si HR, Zhu Y, Li B, Huang CL, Chen HD, Chen J, Luo Y, Guo H, Jiang RD, Liu MQ, Chen Y, Shen XR, Wang X, Zheng XS, Zhao K, Chen QJ, Den GF, Liu LL, Yan B, Zhan FX, Wang YY, Xiao GF, Shi ZL (2020) A pneumonia outbreak associated with a new coronavirus of probable bat origin. Nature 579(7798):270-273 
56. Bosch BJ, Van der Zee R, De Haan CA, Rottier PJM (2003) The coronavirus spike protein is a class I virus fusion protein: structural and functional characterization of the fusion core complex. J Virol 77(16):8801-8811

57. Tortorici MA, Walls AC, Lang Y, Wang C, Li Z, Koerhuis D, Boons GJ, Bosch BJ, Rey FA, Groot RJ, Veesler D (2019) Structural basis for human coronavirus attachment to sialic acid receptors. Nat Struct Mol Biol 26(6):481-489

58. Burkard C, Verheije MH, Wicht O, van Kasteren SI, van Kuppeveld FJ, Haagmans BL, Pelkmans L, Rottierm PJ, Bosch BJ, de Haan CA (2014) Coronavirus cell entry occurs through the endo-/lysosomal pathway in a proteolysis-dependent manner. PLoS Pathog 10(11):e1004502

59. Kirchdoerfer RN, Cottrell CA, Wang N, Pallesen J, Yassine HM, Turner HL, Corbett KS, Graham BS, Mclellan JS, Ward AB (2016) Pre-fusion structure of a human coronavirus spike protein. Nature 531(7592):118-121

60. Millet JK, Whittaker GR (2014) Host cell entry of Middle East respiratory syndrome coronavirus after two-step, furinmediated activation of the spike protein. Proc Natl Acad Sci 111(42):15214-15219

61. Park JE, Li K, Barlan A, Fehr AR, Perlman S, McCray PB, Gallagher T (2016) Proteolytic processing of Middle East respiratory syndrome coronavirus spikes expands virus tropism. Proc Natl Acad Sci 113(43):12262-12267

62. Walls AC, Tortorici MA, Bosch BJ, Frenz B, Rottier PJ, DiMaio F, Rey FA, Veesler D (2016) Cryo-electron microscopy structure of a coronavirus spike glycoprotein trimer. Nature 531(7592):114-117

63. Madu IG, Roth SL, Belouzard S, Whittaker GR (2009) Characterization of a highly conserved domain within the severe acute respiratory syndrome coronavirus spike protein S2 domain with characteristics of a viral fusion peptide. J Virol 83(15):7411-7421

64. Millet JK, Whittaker GR (2015) Host cell proteases: Critical determinants of coronavirus tropism and pathogenesis. Virus Res 202:120-134

65. Belouzard S, Chu VC, Whittaker GR (2009) Activation of the SARS coronavirus spike protein via sequential proteolytic cleavage at two distinct sites. Proc Natl Acad Sci 106(14):5871-5876

66. Heald-Sargent T, Gallagher T (2012) Ready, set, fuse! The coronavirus spike protein and acquisition of fusion competence. Viruses 4(4):557-580

67. Walls AC, Tortorici MA, Snijder J, Xiong X, Bosch BJ, Rey FA, Veesler D (2017) Tectonic conformational changes of a coronavirus spike glycoprotein promote membrane fusion. Proc Natl Acad Sci USA 114(42):11157-11162. https://doi.org/10.1073/ pnas. 1708727114

68. Bergmann CC, Lane TE, Stohlman SA (2006) Coronavirus infection of the central nervous system: host-virus stand-off. Nat Rev Microbiol 4(2):121-132

69. White JM, Delos SE, Brecher M, Schornberg K (2008) Structures and mechanisms of viral membrane fusion proteins: multiple variations on a common theme. Crit Rev Biochem Mol Biol 43(3):189-219

70. White JM, Whittaker GR (2016) Fusion of enveloped viruses in endosomes. Traffic 17(6):593-614

71. Hoffmann M, Kleine-Weber H, Schroeder S, Krüger N, Herrler T, Erichsen S, Schiergens TS, Herrler G, Wu NH, Nitsche A, Müller MA, Drosten C, Pöhlmann S (2020) SARS-CoV-2 cell entry depends on ACE2 and TMPRSS2 and is blocked by a clinically proven protease inhibitor. Cell 181(2):271-280.e8. https://doi. org/10.1016/j.cell.2020.02.052

72. Guillén J, Kinnunen PK, Villalaín J (2008) Membrane insertion of the three main membranotropic sequences from SARS-CoV S2 glycoprotein. Biochim Biophys Acta 1778(12):2765-2774
73. Lentz BR, Malinin V, Haque ME, Evans K (2000) Protein machines and lipid assemblies: current views of cell membrane fusion. Curr Opin Struct Biol 10(5):607-615

74. Cui J, Li F, Shi ZL (2019) Origin and evolution of pathogenic coronaviruses. Nat Rev Microbiol 17:181-192

75. Sola I, Almazán F, Zúñiga S, Enjuanes L (2015) Continuous and discontinuous RNA synthesis in coronaviruses. Annu Rev Virol 2(1):265-288. https://doi.org/10.1146/annurev-virol ogy-100114-055218

76. Alonso S, Izeta A, Sola I, Enjuanes L (2002) Transcription regulatory sequences and mRNA expression levels in the coronavirus transmissible gastroenteritis virus. J Virol 76(3):1293-1308

77. Zun iga S, Sola I, Alonso S, Enjuanes L (2004) Sequence motifs involved in the regulation of discontinuous coronavirus subgenomic RNA synthesis. J Virol 78:980-994

78. Pasternak AO, van den Born E, Spaan WJ, Snijder EJ (2001) Sequence requirements for RNA strand transfer during nidovirus discontinuous subgenomic RNA synthesis. EMBO J 20:7220-7228

79. Knoops K, Kikkert M, Van Den Worm SH, Zevenhoven-Dobbe JC, Van Der Meer Y, Koster AJ, Mommaas AM, Snijder EJ (2008) SARS-coronavirus replication is supported by a reticulovesicular network of modified endoplasmic reticulum. PLoS Biol 6(9):e226

80. Krijnse-Locker J, Ericsson M, Rottier PJ, Griffiths G (1994) Characterization of the budding compartment of mouse hepatitis virus: evidence that transport from the RER to the Golgi complex requires only one vesicular transport step. J Cell Biol 124(1):55-70

81. Tooze J, Tooze S, Warren G (1984) Replication of coronavirus MHV-A59 in sac-cells: determination of the first site of budding of progeny virions. Eur J Cell Biol 33(2):281-293

82. de Haan CA, Rottier PJ (2005) Molecular interactions in the assembly of coronaviruses. Adv Virus Res 64:165-230

83. Zhou P, Yang XL, Wang XG, Hu B, Zhang L, Zhang W, Si HR, Zhu Y, Li B, Huang CL, Chen HD, Chen J, Luo Y, Guo H, Jiang RD, Liu MQ, Chen Y, Shen XR, Wang X, Zheng XS et al (2020) A pneumonia outbreak associated with a new coronavirus of probable bat origin. Nature 579(7798):270-273. https://doi.org/ 10.1038/s41586-020-2012-7

84. Hamming I, Timens W, Bulthuis ML, Lely AT, Navis G, van Goor H (2004) Tissue distribution of ACE2 protein, the functional receptor for SARS coronavirus. A first step in understanding SARS pathogenesis. J Pathol 203:631-637

85. Monteil V, Kwon H, Prado P, Hagelkruys A, Wimmer RA, Stahl M (2020) Inhibition of SARS-CoV-2 infections in engineered human tissues using clinical-grade soluble human ACE2. Cell 181:905-913

86. Guo J, Huang Z, Lin L, Lv JC (2019) Coronavirus disease 2019 (COVID-19) and cardiovascular disease: a viewpoint on the potential influence of angiotensin-converting enzyme inhibitors/ angiotensin receptor blockers on onset and severity of severe acute respiratory syndrome coronavirus 2 infection. J Am Heart Assoc 2020:9

87. Chu H, Chan JF, Yuen TT, Shuai H, Yuan S, Wang Y, Hu B, Yip CC, Tsang JO, Huang X, Chai Y, Yang D, Hou Y, Chik KK, Zhang X, Fung AY, Tsoi HW, Cai JP, Chan WM, IP JD et al (2020) Comparative tropism, replication kinetics, and cell damage profiling of SARS-CoV-2 and SARS-CoV with implications for clinical manifestations, transmissibility, and laboratory studies of COVID-19: an observational study. Lancet Microbe 1(1):e14-e23. https://doi.org/10.1016/S2666-5247(20)30004-5

88. Guo T, Fan Y, Chen M, Wu X, Zhang L, He T, Wang H, Wan J, Wang X, Lu Z (2020) Cardiovascular implications of fatal outcomes of patients with coronavirus disease 2019 (COVID-19). 
JAMA Cardiol 5(7):811-818. https://doi.org/10.1001/jamac ardio. 2020.1017

89. Verdoni L, Mazza A, Gervasoni A, Martelli L, Ruggeri M, Ciuffreda M, Bonanomi E, D’Antiga L (2020) An outbreak of severe Kawasaki-like disease at the Italian epicentre of the SARS-CoV-2 epidemic: an observational cohort study. Lancet 395(10239):1771-1778. https://doi.org/10.1016/S0140-6736(20) 31103-X

90. Varga Z, Flammer AJ, Steiger P, Haberecker M, Andermatt R, Zinkernagel AS, Mehra MR, Schuepbach RA, Ruschitzka F, Moch H (2020) Endothelial cell infection and endotheliitis in COVID-19. Lancet 395(10234):1417-1418. https://doi.org/10. 1016/S0140-6736(20)30937-5

91. Chen N, Zhou M, Dong X et al (2020) Epidemiological and clinical characteristics of 99 cases of 2019 novel coronavirus pneumonia in Wuhan, China: a descriptive study. Lancet 395:507-513

92. Huang C, Wang Y, Li X et al (2020) Clinical features of patients infected with 2019 novel coronavirus in Wuhan. China Lancet 395:497-506

93. Liu K, Fang YY, Deng Y et al (2020) Clinical characteristics of novel coronavirus cases in tertiary hospitals in Hubei Province. Chin Med J (Engl). https://doi.org/10.1097/CM9.0000000000 000744

94. Xu XW, Wu XX, Jiang XG et al (2020) Clinical findings in a group of patients infected with the 2019 novel coronavirus (SARS-Cov-2) outside of Wuhan, China: retrospective case series. BMJ 368:m606

95. Yang X, Yu Y, Xu J et al (2020) Clinical course and outcomes of critically ill patients with SARS-CoV-2 pneumonia in Wuhan, China: a single-centered, retrospective, observational study. Lancet Respir Med. https://doi.org/10.1016/S2213-2600(20)30079-5

96. Zhou F, Yu T, Du R et al (2020) Clinical course and risk factors for mortality of adult in patients with COVID-19 in Wuhan, China: a retrospective cohort study. Lancet 28:1054

97. Guan WJ, Ni ZY, Hu Y et al (2020) Clinical characteristics of coronavirus disease 2019 in China. N Engl J Med 382:1708

98. Pan XW, Xu D, Zhang H, Zhou W, Wang LH, Cui XG (2020) Identification of a potential mechanism of acute kidney injury during the COVID-19 outbreak: a study based on single-cell transcriptome analysis. Intensive Care Med 46(6):1114-1116. https://doi.org/10.1007/s00134-020-06026-1

99. Yalameha B, Roshan B, Lakkakula VKS, Bhaskar ML (2020) Perspectives on the relationship of renal disease and coronavirus disease 2019. J Nephropharmacol. 9(2):e22

100. Khouchlaa A, Bouyahya A (2020) COVID-19 nephropathy; probable mechanisms of kidney failure. J Nephropathol. 9:e35

101. Braun F, Lütgehetmann M, Pfefferle S, Wong MN, Carsten A, Lindenmeyer MT, Nörz D, Heinrich F, Meißner K, Wichmann D, Kluge S, Gross O, Pueschel K, Schröder AS, Edler C, Aepfelbacher M, Puelles VG, Huber TB (2020) SARSCoV-2 renal tropism associates with acute kidney injury. Lancet 396(10251):597-598

102. Mao L, Jin H, Wang M, Hu Y, Chen S, He Q, Chang J, Hong C, Zhou Y, Wang D, Miao X, Li Y, Hu B (2020) Neurologic manifestations of hospitalized patients with coronavirus disease 2019 in Wuhan China. JAMA Neurol 77(6):683-690

103. Hui KPY, Cheung MC, Perera RAPM et al (2020) Tropism, replication competence, and innate immune responses of the coronavirus SARS-CoV-2 in human respiratory tract and conjunctiva: an analysis in ex-vivo and in-vitro cultures. Lancet Respir Med 8(7):687-695. https://doi.org/10.1016/s2213-2600(20)30193-4

104. Huang C, Wang Y, Li X, Ren L, Zhao J, Hu Y, Zhang L, Fan G, Xu J, Gu X, Cheng Z, Yu T, Xia J, Wei Y, Wu W, Xie X, Yin W, Li H, Liu M, Xiao Y, Gao H, Guo L, Xie J, Wang G, Jiang R, Gao Z, Jin Q, Wang J, Cao B (2020 ) Clinical features of patients infected with 2019 novel coronavirus in Wuhan China. Lancet
395(10223):497-506. https://doi.org/10.1016/S0140-6736(20) 30183-5 (PMID: 31986264)

105. Dienz O, Rud JG, Eaton SM, Lanthier PA, Burg E, Drew A, Bunn J, Suratt BT, Haynes L, Rincon M (2012) Essential role of IL-6 in protection against $\mathrm{H} 1 \mathrm{~N} 1$ influenza virus by promoting neutrophil survival in the lung. Mucosal Immunol 5(3):258-266. https://doi. org/10.1038/mi.2012.2 (PMID: 22294047)

106. Murphy EA, Davis JM, Brown AS, Carmichael MD, Ghaffar A, Mayer EP (2008) Effect of IL-6 deficiency on susceptibility to HSV-1 respiratory infection and intrinsic macrophage antiviral resistance. J Interferon Cytokine Res 28(10):589-595

107. Day CW, Baric R, Cai SX, Frieman M, Kumaki Y, Morrey JD et al (2009) A new mouse-adapted strain of SARS-CoV as a lethal model for evaluating antiviral agents in vitro and in vivo. Virology 395(2):210-222. https://doi.org/10.1016/j.virol.2009. 09.023

108. Zhou F, Yu T, Du R, Fan G, Liu Y, Liu Z, Xiang J, Wang Y, Song B, Gu X, Guan L, Wei Y, Li H, Wu X, Xu J, Tu S, Zhang Y, Chen H, Cao B (2020) Clinical course and risk factors for mortality of adult inpatients with COVID-19 in Wuhan, China: a retrospective cohort study. Lancet 395(10229):1054-1062. https://doi.org/10. 1016/S0140-6736(20)30566-3 (PMID: 32171076)

109. Nyati KK, Masuda K, Zaman MM et al (2017) TLR4-induced NF- $\kappa B$ and MAPK signaling regulate the IL-6 mRNA stabilizing protein Arid5a. Nucleic Acids Res 45(5):2687-2703. https://doi. org/10.1093/nar/gkx064

110. Zhang X, Wu K, Wang D et al (2007) Nucleocapsid protein of SARS-CoV activates interleukin-6 expression through cellular transcription factor NF-kappaB. Virology 365(2):324-335. https://doi.org/10.1016/j.virol.2007.04.009

111. Blanco-Melo D, Nilsson-Payant BE, Liu WC, Uhl S, Hoagland D, Moller R, Jordan TX, Oishi K, Panis M, Sachs D, Wang TT, Schwartz RE, Lim JK, Albrecht RA, TenOever BR (2020) Imbalanced host response to SARS-CoV-2 drives development of COVID-19. Cell 181(5):1036-1045.e9

112. Chen G, Wu D, Guo W, Cao Y, Huang D, Wang H, Wang T, Zhang X, Chen H, Yu H, Zhang X, Zhang M, Wu S, Song J, Chen T, Han M, Li S, Luo X, Zhao J, Ning Q (2020 ) Clinical and immunological features of severe and moderate coronavirus disease 2019. J Clin Invest 130(5):2620-2629

113. Ng OW, Chia A, Tan AT, Jadi RS, Leong HN, Bertoletti A, Tan YJ (2016) Memory T cell responses targeting the SARS coronavirus persist up to 11 years post-infection. Vaccine 34(17):20082014. https://doi.org/10.1016/j.vaccine.2016.02.063 (PMID: 26954467)

114. Kamphuis E, Junt T, Waibler Z, Forster R, Kalinke U (2006) Type I interferons directly regulate lymphocyte recirculation and cause transient blood lymphopenia. Blood 108:3253-3261

115. Liao M, Liu Y, Yuan J, Wen Y, Xu G, Zhao J, Cheng L, Li J, Wang X, Wang F, Liu L, Amit I, Zhang S, Zhang Z (2020) Single-cell landscape of bronchoalveolar immune cells in patients with COVID-19. Nat Med 26(6):842-844

116. Chen N, Zhou M, Dong X, Qu J, Gong F, Han Y, Qiu Y, Wang J, Liu Y, Wei Y, Xia J, Yu T, Zhang X, Zhang L (2020) Epidemiological and clinical characteristics of 99 cases of 2019 novel coronavirus pneumonia in Wuhan, China: a descriptive study. Lancet 395(10223):507-513

117. Lu R, Zhao X, Li J, Niu P, Yang B, Wu H, Wang W, Song H, Huang B, Zhu N, Bi Y, Ma X, Zhan F, Wang L, Hu T, Zhou H, Hu Z, Zhou W, Zhao L, Chen J, Meng Y, Wang J, Lin Y, Yuan J, Xie Z, Ma J, Liu WJ, Wang D, Xu W, Holmes EC, Gao GF, Wu G, Chen W, Shi W, Tan W (2020) Genomic characterisation and epidemiology of 2019 novel coronavirus: implications for virus origins and receptor binding. Lancet 395(10224):565-574

118. Xu XW, Wu XX, Jiang XG, Xu KJ, Ying LJ, Ma CL, Li SB, Wang HY, Zhang S, Gao HN, Sheng JF, Cai HL, Qiu YQ, Li LJ 
(2020) Clinical findings in a group of patients infected with the 2019 novel coronavirus (SARS-Cov-2) outside of Wuhan, China: retrospective case series. BMJ 368:m606

119. National Research Project for SARS, Beijing Group (2004) The involvement of natural killer cells in the pathogenesis of severe acute respiratory syndrome. Am J Clin Pathol 121(4):507-511

120. Wang F, Nie J, Wang H, Zhao Q, Xiong Y, Deng L, Song S, Ma Z, Mo P, Zhang Y (2020) Characteristics of peripheral lymphocyte subset alteration in COVID-19 pneumonia. J Infect Dis 221(11):1762-1769

121. Yeager CL, Ashmun RA, Williams RK, Cardellichio CB, Shapiro LH, Look AT, Holmes KV (1992) Human aminopeptidase $\mathrm{N}$ is a receptor for human coronavirus 229E. Nature 357(6377):420-422

122. Kaushansky K (2008) Historical review: megakaryopoiesis and thrombopoiesis. Blood 111(3):981-986

123. Karagiannis P, Eto K (2015) Manipulating megakaryocytes to manufacture platelets ex vivo. J Thromb Haemost 13(Suppl 1):S47-S53

124. Niinikoski J, Goldstein R, Linsey M, Hunt TK (1973) Effect of oxygen-induced lung damage on tissue oxygen supply. Acta Chir Scand 139(7):591-595

125. Martin JF, Slater DN, Trowbridge EA (1983) Abnormal intrapulmonary platelet production: a possible cause of vascular and lung disease. Lancet 1(8328):793-796
126. Levi M, Scully M (2018) How I treat disseminated intravascular coagulation. Blood 131(8):845-854. https://doi.org/10.1182/ blood-2017-10-804096

127. Ranucci M, Ballotta A, Di Dedda U, Bayshnikova E, Dei Poli M, Resta M, Falco M, Albano G, Menicanti L (2020) The procoagulant pattern of patients with COVID-19 acute respiratory distress syndrome. J Thromb Haemost 18(7):1747-1751

128. Lippi G, Bonfanti L, Saccenti C, Cervellin G (2014) Causes of elevated D-dimer in patients admitted to a large urban emergency department. Eur J Intern Med 25(1):45-48

129. Pierron D, Pereda-Loth V, Mantel M et al (2020) Smell and taste changes are early indicators of the COVID-19 pandemic and political decision effectiveness. Nat Commun 11:5152

130. Butowt R, Bilinska K (2020) SARS-CoV-2: olfaction, brain infection, and the urgent need for clinical samples allowing earlier virus detection. ACS Chem Neurosci 11(9):1200-1203

131. Wang WK, Chen SY, Liu IJ et al (2004) Detection of SARS-associated coronavirus in throat wash and saliva in early diagnosis. Emerg Infect Dis 10(7):1213-1219

Publisher's Note Springer Nature remains neutral with regard to jurisdictional claims in published maps and institutional affiliations. 